\title{
Paediatric kidney transplantation in under-resourced regions-a panoramic view
}

\author{
Arpana lyengar $^{1}$ (D) $\cdot$ M. I. McCulloch ${ }^{2}$
}

Received: 19 April 2020 / Revised: 21 July 2020 / Accepted: 24 March 2021 / Published online: 10 April 2021

(C) IPNA 2021

\begin{abstract}
Kidney transplantation is the ideal choice of kidney replacement therapy in children as it offers a low risk of mortality and a better quality of life. A wide variance in the access to kidney replacement therapies exists across the world with only $21 \%$ of low- and low-middle income countries (LLMIC) undertaking kidney transplantation. Pediatric kidney transplantation rates in these underresourced regions are reported to be as low as $<4$ pmcp [per million child population]. A robust kidney failure care program forms the cornerstone of a transplant program. Even the smallest transplant program entails a multidisciplinary workforce and expertise besides ensuring family commitment towards long-term care and economic burden. In general, the short-term graft survival rates from under-resourced regions are comparable to most high-income countries (HIC) and the challenge lies in the long-term outcomes. This review focuses on specific issues relevant to kidney transplants in children in under-resourced regions by highlighting limitations in the capacity and health workforce, regulatory norms, medical issues, economic burden, factors beyond financial hardship and ethical considerations relevant to these regions. Finally, the perspective of strengthening transplant programs in these regions should factor in the bigger challenges that exist in achieving the health-related sustainable development goals by 2030 .
\end{abstract}

Keywords Paediatric kidney transplantation · Low middle-income countries · Under-resourced regions · Developing nations · Challenges $\cdot$ Barriers $\cdot$ Outcomes

\section{The ideal kidney replacement therapy}

The choice of kidney replacement therapy for children with kidney failure should ensure a lower risk of morbidity and mortality and provide a better quality of life. In this regard, kidney transplantation is the ideal choice of kidney replacement therapy in children [1, 2]. Globally, in recent times, improved patient and graft survival have been observed with pre-emptive transplantation [3, 4]. Despite known advantages of living donor transplantation, with nearly $80 \%$ of living donors being parents of the child, the North American Pediatric Renal Transplant Cooperative Study (NAPRTCS) reveals that only one third of paediatric transplants arise from

Arpana Iyengar

arpanaiyengar@gmail.com

1 Pediatric Nephrology, St John's Medical College Hospital, Bangalore India

2 Pediatric Nephrology, Red Cross War Memorial Children's Hospital, Cape Town South Africa a living-related donor (LRD) [5]. Deceased organ transplant is beneficial to children in specific situations and in addition provides an opportunity for a potential second transplant with an LRD [4, 6]. While the world is striving to achieve the sustainable developmental goals (SDG) by 2030 , child health care has taken centre stage. Investment towards achieving this goal has been proposed to be highly cost-effective in the long term [7], providing the unique opportunity to highlight various issues concerning the care of a child with kidney failure needing transplantation in low-resource settings.

\section{Access to kidney transplantation}

Amongst 215 countries across the globe, there are 82 countries which can be classified as low-middle- and low-income countries (LLMIC) [8]. These countries have a greater prevalence of chronic kidney disease (CKD) and death due to CKD in younger individuals (including adolescents) compared to high-income countries (HIC) on the global disease burden analysis [9]. 
In addition, according to the Global Kidney Health Atlas, there is also a wide variation in access to kidney transplantation which is not available in $21 \%$ of countries $(64 \%$ of African countries and $88 \%$ of LIC) $[10,11]$. Kidney transplant rates in adults per million population (pmp) are 40.54 and 35.54 among HIC such as America and those in Europe, respectively, as shown in Fig. 1. In contrast, South-East Asian countries and those in Africa have the lowest rates of transplantation of $7.25 \mathrm{pmp}$ and $1.33 \mathrm{pmp}$, respectively, and minimal deceased organ transplant activity in particular [12]. In Europe, rates of paediatric kidney transplants range from 0 to 13.5 per million children population (pmcp) [13]. Similar data for paediatric kidney transplants is very limited from LLMIC, some reporting rates of paediatric kidney transplantation as low as $<4$ pmcp [14-16]. Moreover, the COVID-19 pandemic has added to the existing disparities in kidney transplantation rates across regions [12].

Even a small kidney transplant program demands a multidisciplinary workforce, high levels of expertise, and family commitment and an ability for patient follow-up with drug monitoring. Several gaps involving resource availability, capacity building, strategy development, and regulatory oversight exist in LLMIC. Across 32 countries in Europe, a strong association was observed between country income based on the GDP per capita and the rates of paediatric kidney transplantation. For every US $\$ 1000$ increase in GDP per capita, the kidney transplant rate increased by 0.2 [13]. However, analysis of geographic measures of socioeconomic status from the United Nations Organ Sharing (UNOS) registry data revealed that socioeconomic status did not predict 1-year paediatric kidney transplant outcomes [17]. In LLMIC, in addition to economic disparities, access to transplantation to an extent is influenced by racial, ethnic and geographical disparities [18-20]. Similar observations have been reported from a country-wide study in Brazil. Among 271 paediatric kidney transplants from Brazil, disparities in access to transplants across various regions were related to large differences in health care resources and economic status within the regions [21].

\section{Kidney failure care-the stepping stone}

Outcomes in transplantation rely on a sound kidney failure care program. LLMIC have unique challenges regarding kidney failure care in adults [22] and children [23]. To a large extent, the status of kidney failure care in children depends on the standards of adult kidney care existing in the region. The real challenge that under-resourced regions or LLMIC face is prompt detection of CKD in children, early referral and providing optimal CKD 5D care services. The ground reality is that despite considerable progress in health care in recent years, the proportion of children presenting for the first time in late stages of CKD persists at around $25 \%$ over the last two

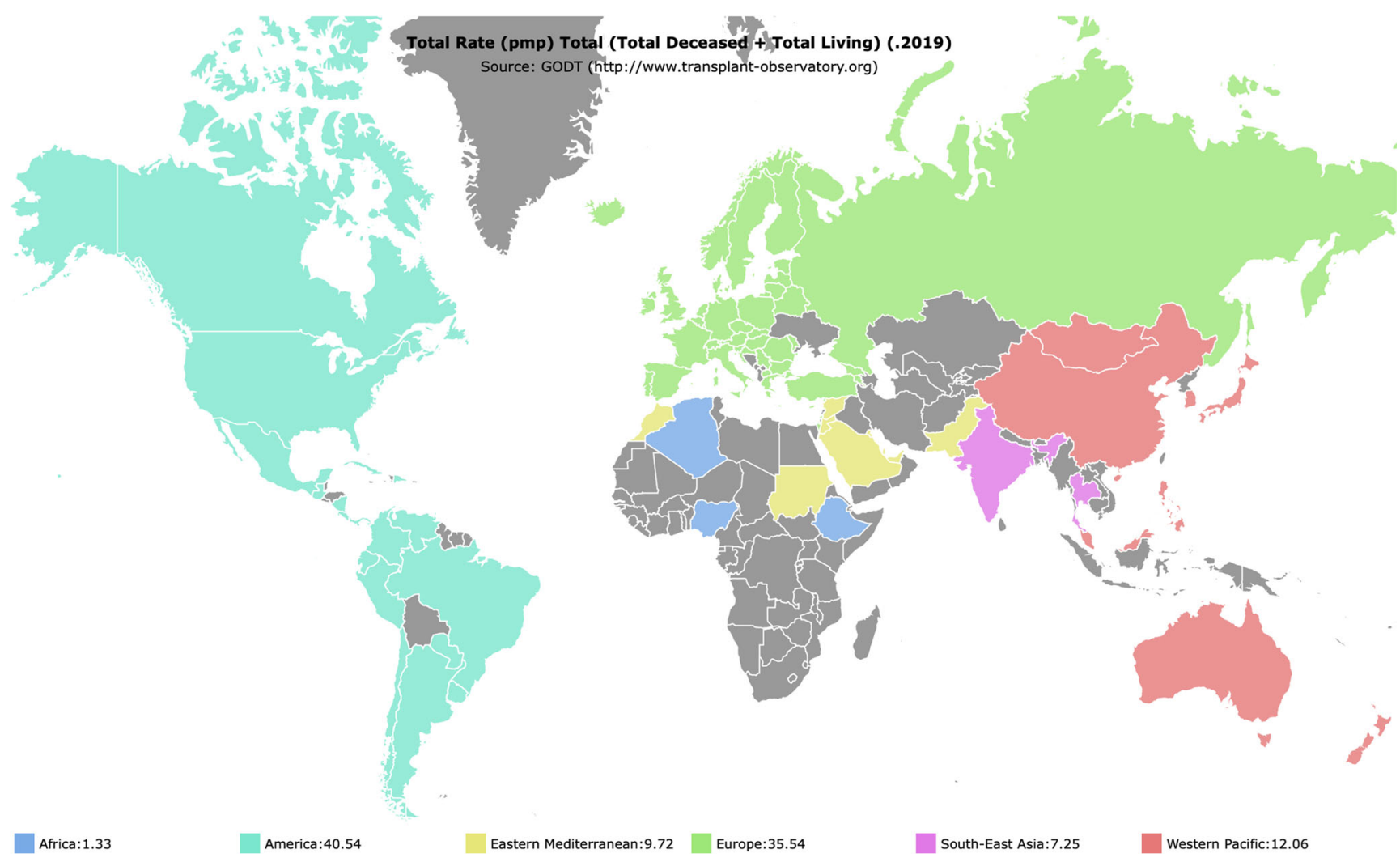

Fig. 1 Total rate (pmp) of kidney transplants undertaken across regions from the global database on donation and transplantation website 
decades in India [24, 25]. Inequalities impact several steps in the overall process from diagnosis of kidney failure to receiving a transplant at country, institution and family levels [26].

Studies from a tertiary Indian centre report higher burden of CKD comorbidities and faster rates of CKD progression compared to HIC [25, 27]. Besides, an alarming observation from the same centre included a significant $(42 \%)$ proportion of children with CKD 5 being lost to follow-up with discontinuation of care while only $20 \%$ underwent transplantation [28]. In resource-limited settings, many of these children present late with life-threatening complications or CKD 5 requiring urgent dialysis that makes pre-emptive transplantation impractical. These situations demand optimal resources, infrastructure and availability of trained health personnel $[29,30]$. On a positive note, parental acceptance of manual chronic peritoneal dialysis especially in younger children in resourceconstrained settings is improving, which may pave the way for transplantation in younger children and infants in these regions [31, 32].

To facilitate better preparation for and to maximise sustainability of kidney replacement therapies in areas with resourcelimited regions, the International Society of Nephrology (ISN) is developing guidance documents applicable to both adults and children for the World Health Organisation. A recent review addresses the various components involved in incorporating transplantation within integrated care for kidney care [33]. From a national level perspective, the key areas governing sustainable transplant services include legislation, regulation, health finance, health workforce, family and community involvement, maintenance of registries, strengthening deceased organ transplant programs and abiding by ethical standards. The essential components needed for a sustainable transplant program at specific levels of health care are depicted in Fig. 2.

\section{Dearth of national registries}

A major limitation that needs to be addressed regarding priorities is the lack of national registries for CKD 5, dialysis or kidney transplantation in the majority of underresourced nations. The paucity of comprehensive health information systems curtails the potential to capture critical information on the burden, needs and provision of kidney replacement therapies including transplantation in these regions. Adult transplant registries exist in 44\% of LMIC and none in LIC $[10,11]$. In fact, populous nations like India and Germany, and parts of Africa, do not have a registry for kidney transplantation [34]. However, countries like Brazil, Thailand and South Africa have made appreciable progress by establishing paediatric kidney transplant registries [35-37]. The various dimensions and utility of registry data as a source of evidence beyond randomised controlled trials have been well discussed with regard to kidney and liver transplantation [38]. Registry management needs to be staffed by a committee that involves all
Fig. 2 Essential components of a sustainable paediatric transplant program at various levels of health care relevant to LLMIC based on reference 33 . *Universal health coverage

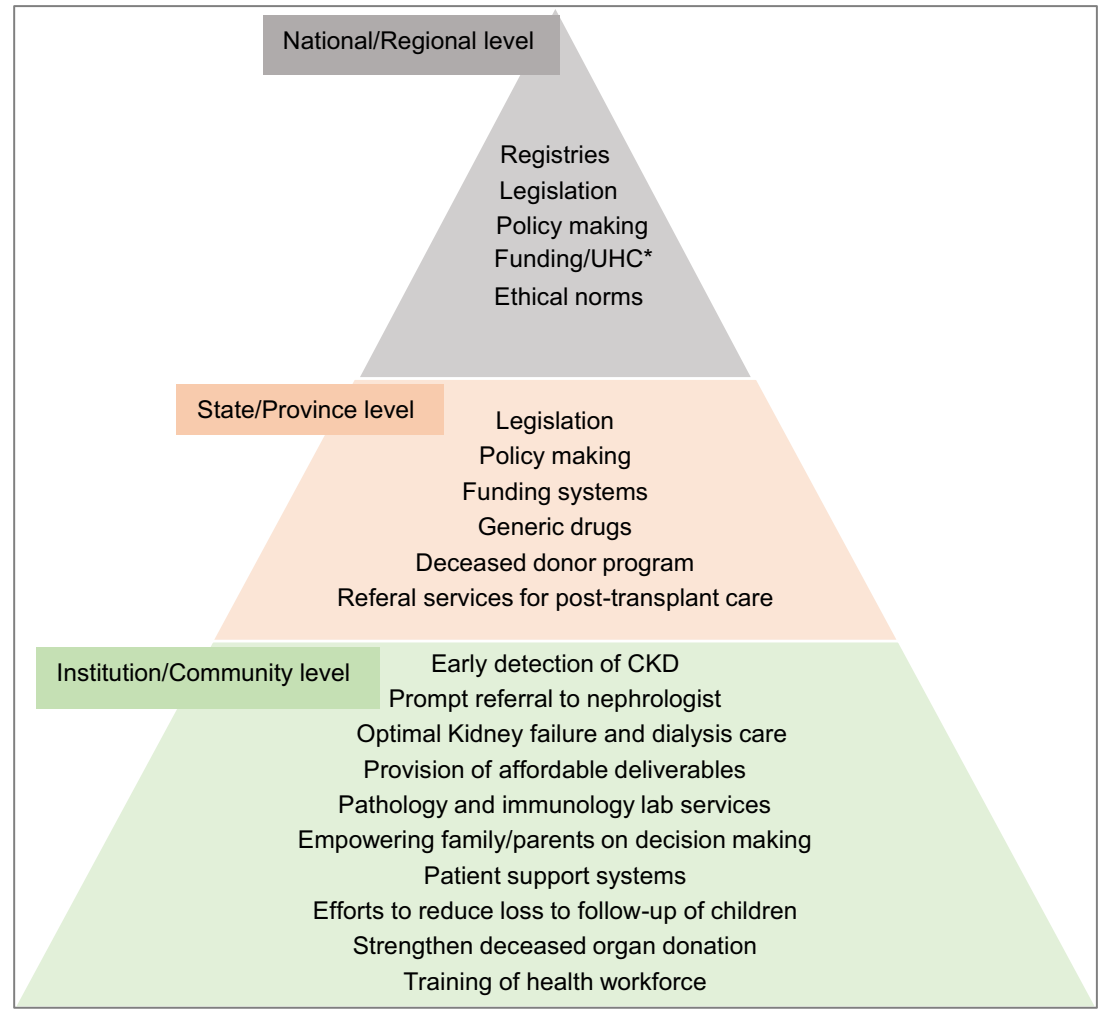


stakeholders who ensure mandatory reporting, provision of adequate technology infrastructure, human workforce and sources for funding. Voluntary participation is the norm for most national registries which requires extensive "buy-in" with ongoing motivation and is most often governed by national societies or bodies rather than the government. Data collection can be a significant challenge but new electronic databases available on smart phone technology have made this easier.

\section{Transplant outcomes in LMIC}

The updated NAPRTCS data (2012-2017) reports graft survival rates at 1 year, 3 years and 5 years of $99.5 \%, 97.2 \%$ and $94.9 \%$ in living donor transplants and $97.6 \%, 94.4 \%$ and $90.1 \%$, respectively, in deceased donor transplants [4]. The allograft survival rates from LLMIC are depicted in Table 1 $[15,39-55]$. Though the 1-year allograft survival rates are quite similar to the NAPRTCS report, the outcomes at 5 years and beyond pose major concerns in these countries. Key factors associated with graft loss have been deceased donor transplant (with resultant increased cold ischaemic times and "less than perfect" older donors), invasive infections, cytomegalovirus disease and more than two rejection episodes, with sepsis being the key contributor to patient loss [41, 43-56]. The unfortunate event of patient loss with an underlying functional allograft is not an uncommon scenario. Predictors of chronic rejection are secondary to poor compliance, lack of induction therapy and multiple episodes of acute rejection [44]. Access to support services, including transplant histopathology, monitoring of viral load and drug level, access to vaccines, imaging and immunology tests are limited in most LLMIC that contribute to suboptimal outcomes [57]. Adolescent patients often fall between services and adolescent care is a challenging field especially in under-resourced regions. Planned transition and development of specific adolescent clinics with ageappropriate treatment and psychological support improve engagement with health services and ultimately improve compliance. This is really important for resource-limited adult services [58].

Most LLMIC initiate transplant services through a living related donor program. Development of a deceased donor program is challenging in the developing world as it demands changes in legislation (brain death legislation), better infrastructure, community involvement, support from intensive care teams, rapid turn-around of transplant immunology services and interventions to address educational, social and religious barriers to organ donation. Currently of 54 countries in Africa, only 4 have brain death legislation (South Africa, Tunisia, Egypt and Sudan). Besides, due to a huge demand for organs amongst adults, there is resistance to enforcing prioritised allocation criteria for children in these regions, leading to prolonged waiting periods for children and adolescents. This often leads to poor growth and failure to thrive with developmental delay and chronic issues of rickets and anaemia. There needs to be a visionary move towards paediatric recipients receiving solid organs from paediatric deceased donors, which is currently not a practice even in the best of centres in LLMIC countries. Deceased donor donation has been the predominant approach to transplanting in children in countries like South Africa (58\%), Chile (61\%), Saudi Arabia (56\%) and Brazil (32\%) with limited data available from other LMIC [48, 59]. Thailand reported a comparable 5 -year graft survival between children receiving living related and deceased donor transplants [48]. An Indian study of 37 children who received deceased donor kidney transplants at a government institution demonstrated 1-year, 5-year and 10-
Table 1 Kidney graft survival of live related transplants in LLMICs

\begin{tabular}{lllll}
\hline Country-wise published data & \multicolumn{4}{l}{ Graft survival \% (LRD) } \\
\cline { 2 - 5 } & $1 \mathrm{yr}$ & $5 \mathrm{yr}$ & $10 \mathrm{yr}$ & $15 \mathrm{yr}$ \\
\hline Brazil [39] & 90 & 72 & 59 & \\
South Africa [40] & 82 & 44 & 23 & $77.6 \%$ (1 centre) \\
India [41-47] & $90-98$ & $80-92$ & $66-85$ & \\
Pakistan [15] & 96 & 81 & - & \\
Thailand [48] & 100 & 86 & - & \\
Iran [49] & 90 & 81 & 62 & \\
Chile [50] & 87 & 78 & - & \\
Egypt [51] & 93 & 73 & - & \\
Turkey [52] & 91 & 67 & - \\
Jordan [53] & 97 & $91(3 \mathrm{yr})$ & - & \\
Saudi Arabia [54] & 98 & 92 & 84 \\
Kuwait [55] & 98 & - &
\end{tabular}


year graft survival rates of $90.4 \%, 73.3 \%$ and $73.3 \%$, respectively [60]. A public-private partnership model for a sustainable donor pool program relevant to developing countries has been set up by the Multi Organ Harvesting and Networking (MOHAN) foundation (http://www.mohanfoundation.org/), a philanthropic non-governmental organization aiming to promote organ donation and transplantation in India. Empowerment of trained transplant coordinators by the foundation led to an appreciable increase $(65 \%)$ in the willingness among families of the deceased to donate organs [61]. Appointment of paediatric transplant co-ordinators can also increase the donation rate in children's health care facilities.

\section{Medical issues}

Native kidney diseases that are known to recur post-transplant, those that warrant genetic testing and those that need combined kidney-liver transplantation pose challenges to paediatric nephrologists in LLMIC. A multi-centre prospective study in 308 children with CKD 5 from the UK observed that barriers to transplantation included disease-related factors in $36 \%$, donor unavailability in $27 \%$ and size of the child in $20 \%$ [62]. A retrospective study of 155 children with CKD 5 from a single LMIC centre revealed non-medical barriers to overshadow medical issues [28]. The medical issues included lack of timely access to deceased donor organs, incomplete bladder preparation among those with urological issues and lack of expertise with multi-organ transplantation as well as lack of expertise in managing transplantation in small children and infants.

Variable outcomes in children transplanted with lower urinary tract dysfunction have been reported from few LMIC, where specific concerns regarding repeated urinary infections, poorer long-term graft function and the need for frequent urological interventions are described [41, 63-65]. An interim analysis of transplanted children with $(n=23)$ and without abnormal lower urinary tract problems $(n=52)$ from the Department of Pediatric Nephrology, St John's Medical College Hospital, revealed suboptimal long-term graft function $[94 \%, 87 \%, 68 \%$ vs. $94 \%, 90 \%, 86 \%]$ and patient survival $[100 \%, 84 \%, 65 \%$ vs. $98 \%, 91 \%, 91 \%]$ at 1 year, 5 years and 10 years, respectively (unpublished data).

Poor growth post-transplant has been a common concern with steroid sparing or avoidance protocols not being followed [44]. In the developed world, a reduction in cardiovascular and infection-related deaths has led to improved survival after paediatric kidney transplantation [66]. A recent study from an LMIC reported a high burden of masked and nocturnal hypertension in paediatric transplant recipients [67].

The spectrum of infections described in children posttransplant includes urinary tract infections, sepsis, pneumonia, tuberculosis, meningitis and viral infections [44, 68].
Infections were noted in $50 \%$ of children post-transplant while sepsis/severe infections contributed to two-thirds of deaths [44]. Death with graft function is common and occurs secondary to sepsis or severe infections among the majority of adults post-transplant [69]. With limited access to molecular diagnostic tests such as real-time polymerase chain reaction, nucleic acid tests and multiplex ligation-dependent probe amplification, the diagnosis of viral infections is delayed causing child morbidity and graft dysfunction. Therapies for viral disease are expensive, further compromising the social and economic security of families.

\section{Capacity and health workforce}

A survey of paediatric kidney transplant practices in India highlights the key concerns that are applicable to LMIC. In stark contrast to well-resourced nations, transplantation in children in the majority of centres was undertaken by adult nephrologists $(61 \%)$ with greater numbers being done in private hospitals [70]. However, most transplants in children undertaken by adult nephrologists include a body weight of $20 \mathrm{~kg}$ and above. A skillful transplant surgeon is indispensable for a successful transplant, to the extent that in some LLMIC centres, there is dependence on transplant surgeons from overseas to facilitate the transplants. Enhancing workforce capacity through training of nurses in transplant and critical care nursing, having paediatric transplantation made mandatory in the curriculum for post-doctoral training and including medical social work services within the framework of multidisciplinary teams are some key steps to strengthen the workforce. A structured and collaborative approach between paediatric and adult nephrologists for transition of adolescents to adult renal services is lacking in most well-established centres.

In many countries in South Asia, public/government hospitals receive a large number of children with CKD and CKD 5 but many are unable to provide kidney replacement therapies for children in particular. Private centres that have the expertise and infrastructure in place have to shoulder the burden of raising funds and cutting costs to make kidney replacement therapies including transplantation affordable to all sectors of society. An example of a public-private partnership model to cater to providing kidney transplant to poorer sectors of society in a LMIC is described for adults [71].

Most successful private specialty hospitals are located in metropolitan cities and some have geared up to perform highly specialised transplant-related procedures like ABO incompatibility and paired organ donation in children [72, 73]. However, a paediatric ABO-incompatible kidney transplant has also been reported from a university teaching hospital in Nepal [74]. The hard fact remains that families belonging to lower-middle and lower socioeconomic segments of society struggle to cope with the challenges of preparing their child 
for transplantation, sustaining long-term expenses, maintaining close follow-up and transition of care of their children to adult service.

\section{Economic barriers}

The most important barrier to transplantation in LLMIC is the high costs involved. The concept that transplantation is not as expensive as long-term dialysis has been proven in adults but can be applied to children as well [75].

Table 2 demonstrates the approximate costs related to paediatric dialysis and transplantation from two centres in LLMIC. We observe a tendency for families to agree to some form of dialysis as an approach to manage the crisis of kidney failure. This happens more so due to children presenting late and needing emergent kidney replacement therapy. Most families thereafter continue with long-term dialysis for several reasons despite being cognizant of the fact that expenditure towards long-term dialysis exceeds that of transplantation. Without the support of insurance, families face out-of-pocket costs that can lead to catastrophic expenditures from any modality of kidney replacement therapy, leading to graft loss in case of transplantation [76, 77]. Public funding for kidney replacement therapy exists in most HIC but is minimal in LLMIC. The need for urgent funding support towards kidney transplantation in children has been recently highlighted in a study from Nigeria [78]. Though some LMIC are providing funding models for dialysis, there is no such support for transplantation as yet [79]. While LLMIC countries are moving towards universal health care, from a policy-making perspective, it becomes important to assess the feasibility and benefits involved in supporting dialysis or transplantation within regions [80]. Maintenance immunosuppression adds to the financial burden of transplantation and a transition from brand to generic drugs could cut costs of life-long therapy [81]. A community-government partnership model for funding paediatric kidney replacement therapies has been implemented in Pakistan [15].

\section{Barriers beyond financial hardship}

Commuting from rural and remote areas to reach tertiary hospitals has been a major concern observed in developing nations for both pre- and post-transplant long-term care [14, 15]. As an example, from a community perspective in India, basic kidney function testing is not done in a village centre or a subcentre. Travel distance to the nearest primary health centre that cares for a population of 20,000-30,000 and has the facility to test for kidney function ranges from 5 to $10 \mathrm{~km}$ and travel to a district hospital for imaging studies may reach $35 \mathrm{~km}$ [82]. Moreover, substantial variability in serum creatinine assays exists in laboratories across levels of health care.

Barriers to accomplishing transplant in an under-resourced setting includes the unique issue of loss to follow-up or disappearance of children and their families from the treatment centre [28]. This is associated with low socioeconomic status, longer time and distance to travel, parent's education and parent's occupation. Negative attitudes towards transplantation and organ donation among parents and families are also encountered. Lack of interest in transplantation was observed in $61 \%$ which included reasons like the father being unwilling to pursue transplantation, focus on the birth of the next child, hope that kidney failure will recover miraculously and competing family health issues. Another issue seen in $15 \%$ was neither parent being fit or willing to donate and unwilling to miss work as daily wage labourers. A qualitative study of children and adolescents found that negative emotions regarding transplantation among children and adolescents included
Table 2 Approximate costs related to paediatric kidney replacement therapies from two centres belonging to LMIC

\begin{tabular}{lll}
\hline Kidney replacement therapies for a child & $\begin{array}{l}\text { India }{ }^{\mathrm{a}} \text { Cost (USD ex rate = 69) } \\
\text { Rounded to nearest USD }\end{array}$ & $\begin{array}{l}\text { South Africa }{ }^{\mathrm{b}} \text { USD } \\
\text { Government } \\
\text { subsidised }\end{array}$ \\
\hline $\begin{array}{l}\text { Maintenance dialysis monthly } \\
\text { CAPD costs (2 bags dialysate } \\
\quad \text { medications + clinic visit) }\end{array}$ & 489 & 650 \\
HD (3 per week) + medications & 311 & 450 \\
$\quad+$ clinic visit) & & \\
$\begin{array}{l}\text { Transplant-related treatment } \\
\text { Cost of LRD transplantation }\end{array}$ & 9420 & 10,800 \\
Monthly immunosuppression & 145 & 390 \\
Monthly transplant clinic visit & 51 & 150 \\
\hline
\end{tabular}

USD United States Dollar, CAPD continuous ambulatory peritoneal dialysis, $H D$ hemodialysis

a St John's Medical College Hospital, Bangalore - a non-government, "not for profit" academic Institution

${ }^{\mathrm{b}}$ Red Cross War Memorial Children's Hospital, University of Cape Town-Government hospital 
fear, anxiety, guilt for burdening siblings and parent as donors [83]. Children and adolescents did view kidney transplantation as freedom from dialysis while knowing that transplantation is not necessarily a return to full health.

\section{Ethical issues}

It is imperative to consider equity in the provision of kidney replacement therapy in LLMIC and this is governed by factors like availability of resources, affordability of treatments and acceptability concerning ethical and societal standards [84]. Issues regarding unregulated organ trade and transplant tourism prevail in these regions $[14,85,86]$. Gender disparities have been recognised with respect to donors and recipients across LMIC [87, 88]. A pragmatic and critical ethical issue is consideration of family resources while making medical recommendations for transplantation (an expensive treatment with no guarantee of success) to a child belonging to a poor family. This discussion includes consideration of principles of beneficence, maleficence, justice and autonomy [89]. A preliminary guidance document on the ethical framework and approach to ethical challenges in kidney failure care, including kidney replacement therapies, has been developed for LMIC but requires further refinement [90].

\section{Steps towards bridging gaps}

Legislation (regarding donors and recipients), regulatory norms, policy advocacy at local hospitals and government departments at health care levels for both children and adolescents, registries, health financing, adherence to ethical standards and community and patient engagement are the key domains that under-resourced nations need to work on to build effective transplant programs. Templates for development of transplant programs as a component of integrated kidney failure care in LLMIC have been put forth by the ISN [33].

Scientific bodies such as the ISN, The Transplantation Society (TTS), the International Pediatric Nephrology Association (IPNA), the International Society of Peritoneal Dialysis (ISPD) and the International Pediatric Transplant Association (IPTA) have invested in unique exchange training programs and educational collaborations. These initiatives have gone a long way in empowering under-resourced countries to undertake transplantation in both adults and children with an additional responsibility of engaging in efforts to solve regional challenges. An example of a collaboration that not only reflects the strengths of collaboration but also projects the specific challenges relevant to an under-resourced region is a centre in Myanmar. A centre in Yangon Hospital, Myanmar, undertook the first paediatric transplantation under the umbrella of the ISN Sister renal centre collaboration in

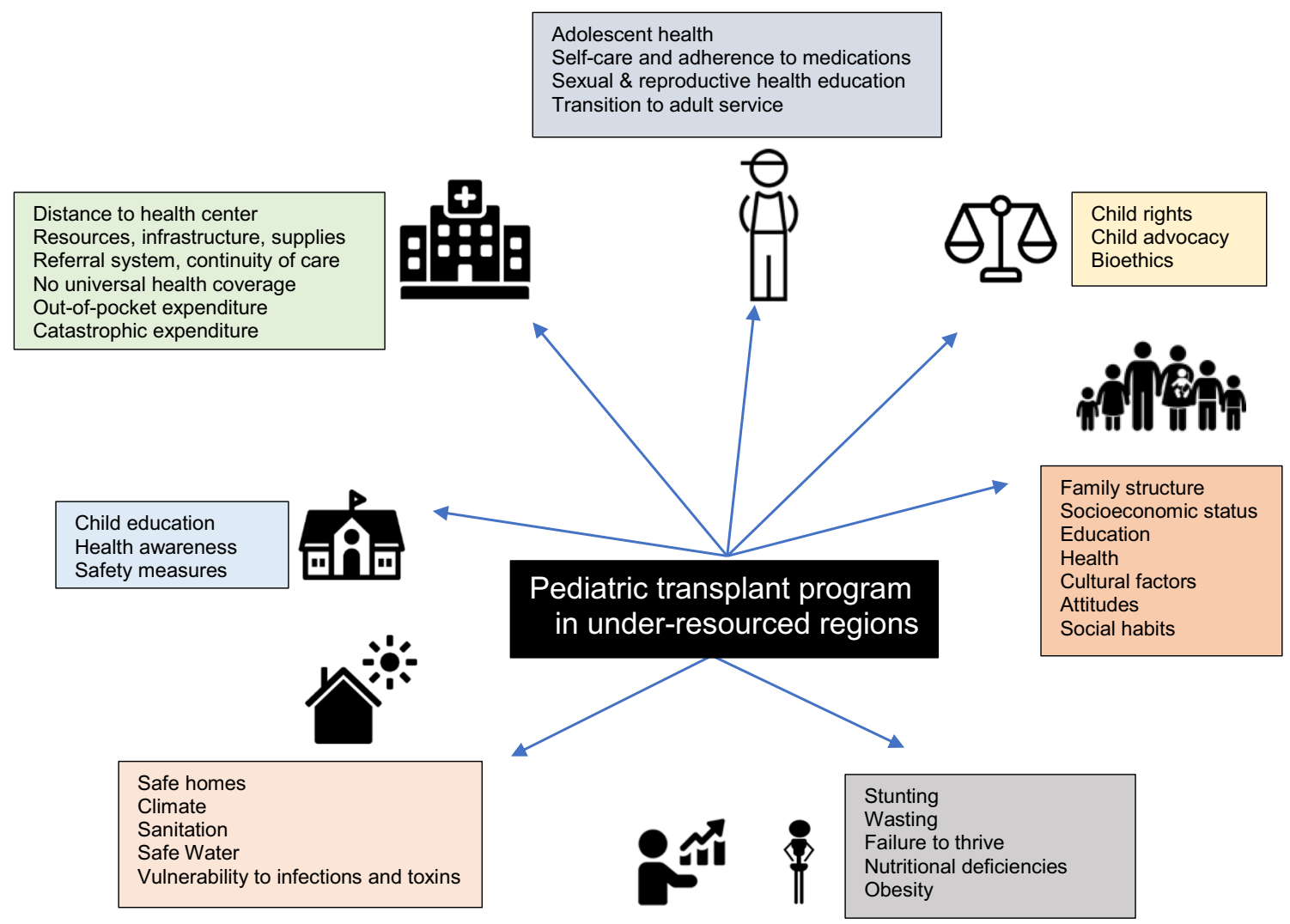

Fig. 3 Components of health-related SDG that potentially impact paediatric transplantation in under-resourced regions [7, 87] 
2017. Under the guidance and mentorship of the team from Children Kidney Centre, National University Hospital, Singapore, kidney failure care services were implemented, pre-transplant preparation was undertaken and ten children received transplants successfully. Key challenges noted were convincing the community and medical fraternity about the need for and feasibility of undertaking transplantation in children, raising funds for the surgery, supporting post-transplant immunosuppression and dealing with various issues of sustaining follow-up care. Medical professionals had to shoulder responsibilities beyond the purview of nephrology care through home visits, ensuring basic water supply, housing and sanitation for the children following transplantation (personal communication with Prof. Yi Yi Khin, Pediatric Nephrologist, Myanmar).

This brings us back to reality. If we take a step back from the transplant scene, we see a panoramic view of the underresourced world that is faced with very basic and complex challenges related to health. Figure 3 illustrates the various health-related SDGs that pose challenges to kidney failure care and transplantation in under-resourced regions. The under-resourced world in particular is battling against healthrelated SDGs like maternal, neonatal and under-five mortality, striving to find ways to deal with a huge burden of basic needs like clean water supply, sanitation hygiene, safe homes and other environmental hazards towards the timeline of 2030 [7, $91,92]$. In this context, it becomes crucial to understand and accept the fact that unless progress towards solving these elementary issues and inequalities impacting child health takes place with the required momentum, kidney failure care and kidney replacement therapies will continue to remain a big challenge in under-resourced regions. However, on a brighter note, as it demands a multidisciplinary approach, development of transplant programs in under-resourced regions will have positive influences on the entire health care system, serving as an impetus to develop and sustain higher standards of health care at all levels in the region.

Acknowledgements We are grateful to Dr. Valerie Luyckx MBBch, $\mathrm{MSc}, \mathrm{PhD}$ (nephrologist with a primary interest in global health and kidney disease in underserved populations and low-resource regions, University of Zurich) for providing valuable input to this review.

\section{Declarations}

Conflict of interest The authors declare no competing interests.

\section{References}

1. Gillen DL, Stehman-Breen CO, Smith JM, McDonald RA, Warady BA, Brandt JR, Wong CS (2008) Survival advantage of pediatric recipients of a first kidney transplant among children awaiting kidney trans-plantation. Am J Transplant 8:2600-2606

2. Yadav P, Nunia S, Bansal A, Sureka SK, Jena R, Ansari MS, Srivastava A (2017) Multidimensional assessment of quality of life of children and problem of parents in India Society after pediatric renal transplant: beyond the conventional thoughts. Pediatr Transplant 21:e13001

3. Amaral S, Sayed BA, Kutner N, Patzer RE (2016) Pre-emptive kidney transplantation is associated with survival benefits among pediatric patients with end-stage renal disease. Kidney Int 90:11001108

4. Chua A, Cramer C, Moudgil A, Martz K, Smith J, Blydt-Hansen T, Neu A, Dharnidharka VR, NAPRTCS investigators (2019) Kidney transplant practice patterns and outcome benchmarks over 30 years: the 2018 report of the NAPRTCS. Pediatr Transplant 23:e13597. https://doi.org/10.1111/petr.13597

5. North American Pediatric Renal Trials and Collaborative Studies (2014) NAPRTCS 2014 Annual Transplant Report. https://naprtcs. org/system/files/2014 Annual Transplant Report.pdf. Accessed 30 March 2021

6. Sigurjonsdottir VK, Grimm PC (2019) Living or deceased donor kidney transplantation in children. Curr Opin Pediatr 31:232-236. https://doi.org/10.1097/mop.0000000000000740

7. Clark H, Coll-Seck AM, Banerjee A, Peterson S, Dalglish SL, Ameratunga S, Costello A, Balabanova D, Bhan MK, Bhutta ZA (2020) A future for the world's children? A WHO-UNICEFLancet Commission. Lancet 395:605-658. https://doi.org/10. 1016/s0140-6736(19)32540-1

8. ChartsBin statistics collector team (2016) Country Income Groups (World Bank Classification). http://chartsbin.com/view/2438. Accessed 4 March 2020

9. Xie Y, Bowe B, Mokdad AH, Xian H, Yan Y, Li T, Al-Aly Z, Maddukuri G, Tsai CY, Floyd T, Al-Aly Z (2018) Analysis of the Global Burden of Disease study highlights the global, regional, and national trends of chronic kidney disease epidemiology from 1990 to 2016. Kidney Int 94:567-581. https://doi.org/10.1016/j.kint. 2018.04.011

10. Bello AK, Levin A, Tonelli M, Okpechi IG, Feehally J, Harris D, et al. (2017) Global Kidney Health Atlas: A Report by the International Society of Nephrology on the Current State of Organization and Structures for Kidney Care Across the Globe. International Society of Nephrology, Brussels, Belgium

11. Bello AK, Levin A, Tonelli M, Okpechi IG, Feehally J, Harris D, Jindal K, Salako BL, Rateb A, Osman MA, Qarni B, Saad S, Lunney M, Wiebe N, Ye F, Johnson DW (2017) Assessment of global kidney health care status. JAMA 317:1864-1881

12. Global Observatory on Donation and Transplantation (2020) Organ Donation and Transplantation Activities 2020. http://www. transplant-observatory.org/2020-activity-data. Accessed March 2021

13. Harambat J, van Stralen KJ, Schaefer F, Grenda R, Jankauskiene A, Kostic M, Macher MA, Maxwell H, Puretic Z, Raes A, Rubik J, Sørensen SS, Toots U, Topaloglu R, Tönshoff B, Verrina E, Jager $\mathrm{KJ}$ (2013) Disparities in policies, practices and rates of pediatric kidney transplantation in Europe. Am J Transplant 13:2066-2074. https://doi.org/10.1111/ajt.12288

14. Spearman CW, McCulloch MI (2014) Challenges for paediatric transplantation in Africa. Pediatr Transplant 18:668-674

15. Rizvi SA, Sultan S, Zafar MN, Naqvi SA, Lanewala AA, Hashmi S, Aziz T, Hassan AS, Ali B, Mohsin R, et al. (2013) Pediatric kidney transplantation in the developing world: challenges and solutions. Am J Transplant 13:2441-2449

16. Garcia C, Pestana JM, Martins S, Nogueira P, Barros V, Rohde R, Camargo M, Feltran L, Esmeraldo R, Carvalho R (2015) Collaborative Brazilian pediatric renal transplant registry 
(CoBrazPed-RTx): a report from 2004 to 2013. Transplant Proc 47: 950-953

17. Miller R, Akateh C, Thompson N, Tumin DH Jr, Black SM, Tobias JD (2018) County socioeconomic characteristics and pediatric renal transplantation outcomes. Pediatr Nephrol 33:1227-1234. https:// doi.org/10.1007/s00467-018-3928-0

18. Chesnaye NC, Schaefer F, Groothoff JW, Caskey F, Heaf JG, Kushnirenko S, Lewis M, Mauel R, Maurer E, Merenmies J (2015) Disparities in treatment rates of paediatric end-stage renal disease across Europe: insights from the ESPN/ERA-EDTA registry. Nephrol Dial Transplant 30:1377-1385

19. Reese PP, Hwang H, Potluri V, Abt PL, Shults J, Amaral S (2014) Geographic determinants of access to pediatric deceased donor kidney transplantation. J Am Soc Nephrol 25:827-835

20. Patzer RE, Mohan S, Kutner N, McClellan WM, Amaral S (2015) Racial and ethnic disparities in pediatric renal allograft survival in the United States. Kidney Int 87:584-592

21. Nogueira PC, de Carvalho MF, de Santis Feltran L, Konstantyner $\mathrm{T}$, Sesso R (2015) Inequality in pediatric kidney transplantation in Brazil. Pediatr Nephrol 31:501-507. https://doi.org/10.1007/ s00467-015-3226-z

22. Luyckx VA, Smyth B, Harris DCH, Pecoits-Filho R (2020) Dialysis funding, eligibility, procurement, and protocols in lowand middle-income settings: results from the International Society of Nephrology collection survey. Kidney Int Suppl 10:e10-e18

23. Lalji R, Francis A, Johnson DW, McCulloch M (2020) Health disparities in access to kidney replacement therapy amongst children and adolescents with end-stage kidney disease in low- and lower-middle-income countries. Kidney Int 97:463-465. https:// doi.org/10.1016/j.kint.2019.11.030

24. Hari P, Singla IK, Mantan M, Kanitkar M, Batra B, Bagga A (2003) Chronic renal failure in children. Indian Pediatr 40:1035-1042

25. Kamath N, Iyengar A (2017) Chronic kidney disease (CKD): an observational study of etiology, severity and burden of comorbidities. Indian J Pediatr 84:822-825. https://doi.org/10.1007/s12098$017-2413-2$

26. Harambat J, Ekulu PM (2015) Inequalities in access to pediatric ESRD care: a global health challenge. Pediatr Nephrol 31:353358. https://doi.org/10.1007/s00467-015-3263-7

27. Kamath N, lyengar A, George N, Luyckx VA (2019) Risk factors and rate of progression of CKD in children. Kidney Int Rep 4: 1472-1477. https://doi.org/10.1016/j.ekir.2019.06.004

28. Pais P, Blydt-Hansen TD, Michael Raj JA, Dello Strologo L, Iyengar A Low renal transplantation rates in children with endstage kidney disease: a study of barriers in a low-resource setting. Pediatr Transplant 25:e13867. https://doi.org/10.1111/petr.13867

29. Niang A, Iyengar A, Luyckx VA (2018) Hemodialysis versus peritoneal dialysis in resource-limited settings. Curr Opin Nephrol Hypertens 27:463-471. https://doi.org/10.1097/mnh. 0000000000000455

30. Savla D, Ahmed S, Yeates K, Matthew A, Anand S (2017) Barriers to increasing use of peritoneal dialysis in Bangladesh: a survey of patients and providers. Perit Dial Int 7:234-237. https://doi.org/10. 3747/pdi.2016.00177

31. Kamath N, Reddy HV, Iyengar A (2020) Clinical and dialysis outcomes of manual chronic peritoneal dialysis in low-body-weight children from a low-to-middle-income country. Perit Dial Int 40: 6-11. https://doi.org/10.1177/0896860819873541

32. Jain AK, Blake P, Cordy P, Garg AX (2012) Global trends in rates of peritoneal dialysis. J Am Soc Nephrol 23:533-544

33. O'Connell PJ, Brown M, Chan TM, Claure-Del Granado R, Davies SJ, Eiam-Ong S, Hassa MH, Kalantar-Zadeh K, Levin A, Martin DE (2020) The role of kidney transplantation as a component of integrated care for chronic kidney disease. Kidney Int Suppl 10: e78-e85. https://doi.org/10.1016/j.kisu.2019.11.006
34. See EJ, Alrukhaimi M, Ashuntantang GE, Bello AK, Bellorin-font E, Benghanem Gharbi M, Braam B, Feehally J, Harris DC, Jha V (2018) Global coverage of health information systems for kidney disease: availability, challenges, and opportunities for development. Kidney Int Suppl 8:74-81

35. De Souza VC, Garcia CD, Pestana JM, Stopa Martins SB, Porini Custódio L d F, Bittencourt V, Rohde R, Simoes Pires I, Camargo MF, Koch Nogueira P, et al. (2019) Collaborative Brazilian pediatric renal transplant registry (CoBrazPed-RTx): a report from 2004 to 2018. Pediatr Transplant 23:e13463. https://doi.org/10.1111/ petr. 13463

36. Noppakun K, Ingsathit A, Pongskul C, Premasthian N, Avihingsanon Y, Lumpaopong A, Vareesangthip K, Sumethkul $\mathrm{V}$, Subcommittee for kidney transplant registry, Thai Transplantation Society (2015) A 25-year experience of kidney transplantation in Thailand: Report from the Thai Transplant Registry. Nephrology 20:177-183. https://doi.org/10.1111/nep. 12378

37. Davids MR, Eastwood JB, Selwood NH, Arogundade FA, Ashuntantang G, Benghanem GharbiM Jarraya F, McCulloch M, Plange-Rhule J, Swanepoel CR, Adu D (2016) A renal registry for Africa: first steps. Clin Kidney J 9:162-167. https://doi.org/10. 1093/ckj/sfv122

38. Wadström J, Ericzon BG, Halloran PF, Bechstein WO, Opelz G, Serón D, Grinyó J, Loupy A, Kuypers D, Mariat C (2017) Advancing transplantation. Transplantation 101(Suppl 2S):S1S41. https://doi.org/10.1097/tp.0000000000001563

39. Garcia CD, Bittencourt VB, Tumelero A, Antonello JS, Moura DM, Vitola SP, Didone E, Guerra E, Pires F, Garcia VD (2006) 300 pediatric renal transplantations: a single-center experience. Transplant Proc 38:3454-3455. https://doi.org/10.1016/j. transproceed.2006.10.086

40. Pitcher GJ, Beale PG, Bowley DM, Hahn D, Thomson PD (2006) Pediatric renal transplantation in a South African teaching hospital: a 20-year perspective. Pediatr Transplant 10:441-448. https://doi. org/10.1111/j.1399-3046.2006.00489.x

41. Chacko B, Rajamanickam T, Neelakantan N, Tamilarasi V, John GT (2007) Pediatric renal transplantation - a single center experience of 15yr from India. Pediatr Transplant 11:844-849. https://doi. org/10.1111/j.1399-3046.2007.00774.x

42. Vasudevan A, Iyengar A, Jose B, Phadke K (2008) Pediatric Renal Transplantation: A Single-Center Experience. Transplant Proc 40: 1095-1098

43. Sinha A, Hari P, Guleria S, Gulati A, Dinda AK, Mehra NK, Srivastava RN, Bagga A (2010) Outcome of pediatric renal transplantation in north India. Pediatr Transplant 14:836-843. https:// doi.org/10.1111/j.1399-3046.2010.01394.x

44. Meena J, Sinha A, Hari P, Dinda AK, Khandelwal P, Goswami S, Srivastava RN, Guleria S, Gulati A, Bansal VK, et al. (2018) Pediatric kidney transplantation: experience over two decades. Asian J Pediatr Nephrol 1:22-28

45. Srivastava A, Prabhakaran S, Sureka SK, Kapoor R, Kumar A, Sharma RK, Prasad N, Ansari MS (2015) The challenges and outcomes of living donor kidney transplantation in pediatric and adolescent age group in a developing country: a critical analysis from a single center of north India. Indian J Urol 31:33-37. https://doi.org/ 10.4103/0970-1591.145290

46. Phadke K, Iyengar A, Karthik S, Kumar A, Olakkengil S (2006) Pediatric renal transplantation: the Bangalore experience. Indian Pediatr 43:44-48

47. Bijalwan P, Sanjeevan KV, Mathew A, Nair TB (2017) Outcome and complications of living donor pediatric renal transplantation: experience from a tertiary care center. Indian J Urol 33:221-225. https://doi.org/10.4103/iju.IJU_382_16

48. Chantarogh S, Tangnararatchakit K, Tirapanich W, Viseshsindh W, Saisawat P, Pirojsakul K (2017) Clinical outcomes in pediatric renal 
transplant recipients who received steroid-based immunosuppressive regimen. Transplant Proc 49:971-976. https://doi.org/10.1016/ j.transproceed.2017.03.027

49. Naderi G, Latif A, Karimi S, Tabassomi F, Esafahani ST (2017) The long-term outcome of pediatric kidney transplantation in Iran: results of a 25 -year single-center cohort study. Int J Organ Transplant Med 8:85-96

50. Rosati P, Pinto V, Delucchi A, Salas P, Cano F, Zambrano P, Lagos E, Rodriguez E, Hevia P, Ramirez K, et al. (2005) Pediatric renal transplantation: 13 years of experience - report from the Chilean Cooperative Multicenter Group. Transplant Proc 37:1569-1573

51. El-Husseini AA, Foda MA, Bakr MA, Shokeir AA, Sobh MA, Ghoneim MA (2006) Pediatric live-donor kidney transplantation in Mansoura Urology \& Nephrology Center: a 28 -year perspective. Pediatr Nephrol 21:1464-1470

52. Sözen H, Dalgic A, Karakayali H, Baskin E, Saatci U, Arslan G, Haberal M, et al. (2006) Renal transplantation in children. Transplant Proc 38:426-429

53. Shilbayeh S, Hazza I (2012) Pediatric renal transplantation in the Jordanian population: the clinical outcome measures during longterm follow-up period. Pediatr Neonatol 53:24-33

54. Souqiyyeh MZ, Al-Khader AA, Shaheen FA, Huraib SO, Al-Harbi M (1997) Pediatric renal transplantation in Saudi Arabia. Saudi J Kidney Dis Transpl 8:302-309

55. Samhan M, Fathi T, Al-Kandari N, Buresley S, Nampoory MR, Niar P, Halim M, AI-Mousawi M, et al. (2007) Renal transplantation in children. Transplant Proc 39:911-913

56. Akoh JA (2011) Renal transplantation in developing countries. Saudi J Kidney Dis Transpl 22:637-650

57. Mubarak M (2012) Practicing renal transplant pathology in a developing country: challenges and opportunities. J Transplant Technol Res 2:e118. https://doi.org/10.4172/2161-0991.1000e118

58. Davidson B, Okpechi I, McCulloch M, Wearne N (2017) Adolescent nephrology: an emerging frontier for kidney care in sub-Saharan Africa. Nephrology 22:933-939. https://doi.org/10. 1111/nep.13135

59. Moosa MR (2019) The state of kidney transplantation in South Africa. S Afr Med J 109:235. https://doi.org/10.7196/samj.2019. v109i4.13548

60. Kute VB, Trivedi HL, Vanikar AV, Shah PR, Gumber MR, Patel HV, Munjappa BC, Modi PR, Gera DN (2012) Long-term outcome of deceased donor renal transplantation in pediatric recipients: a single-center experience from a developing country. Pediatr Transplant 16:651-657. https://doi.org/10.1111/j.1399-30146. 2012.01746x

61. Abraham G, Vijayan M, Gopalakrishnan N, Shroff S, Amalorpavanathan J, Yuvaraj A, Nair S, Sundarrajan S (2016) State of deceased donor transplantation in India: a model for developing countries around the world. World J Transplant 6:331335. https://doi.org/10.5500/wjt.v6.i2.331

62. Kim JS, Marlais M, Balasubramanian R, Muorah M, Inward C, Smith GC, Reynolds BC, Yadav P, Morgan H, Shenoy M, Tse Y, Hussain F, Grylls S, Kessaris N, Sinha MD, Marks SD, British Association for Paediatric Nephrology (2020) UK national study of barriers to renal transplantation in children. Arch Dis Child 106: 384-386. https://doi.org/10.1136/archdischild-2019-318272

63. Ali-El-Dein B, Abol-Enein H, El-Husseini A, Osman Y, Shehab ElDin AB, Ghoneim MA (2004) Renal transplantation in children with abnormal lower urinary tract. Transplant Proc 36:29682973. https://doi.org/10.1016/j.transproceed.2004.11.095

64. Maison POM, Smit S, McCulloch M, Gajjar P, Nourse P, Thomson D, Muller E, Millar A, Numanoglu A, Khan D (2017) Urological complications following unstented pediatric renal transplantation. Pediatr Transplant 21:e13045. https://doi.org/10.1111/petr.13045
65. Mishra SK, Muttu V, Rajapurkar MM, Desai MR (2007) Kidney transplantation in abnormal bladder. Indian J Urol 23:299-304. https://doi.org/10.4103/0970-1591.33728

66. Francis A, Johnson DW, Melk A, Foster BJ, Blazek K, Craig JC, Wong G (2020) Survival after kidney transplantation during childhood and adolescence. Clin J Am Soc Nephrol 15:392-400. https:/ doi.org/10.2215/CJN.07070619

67. Pais P, Dello Strologo L, Iyengar A, Velusamy V, Greenbaum LA (2020) Nocturnal hypertension and left ventricular hypertrophy in pediatric renal transplant recipients in South India. Pediatr Transplant 24:e13710. https://doi.org/10.1111/petr.13710

68. Ullah K, Reza S, Ahmed P, Chaudhry QU, Satti TM, Ahmed S, Mirza SH, Akhtar F, Kamal K, Akhtar FM (2008) Posttransplant infections: single centre experience from the developing world. Int $\mathrm{J}$ Infect Dis 12:203-214

69. Prakash J, Ghosh B, Singh S, Soni A, Rathore SS (2012) Causes of death in renal transplant recipients with functioning allograft. Indian J Nephrol 22:264-268. https://doi.org/10.4103/0971-4065.101245

70. Sethi SK, Sinha R, Rohatgi S, Kher V, Iyengar A, Bagga A (2017) Pediatric renal transplant practices in India. Pediatr Transplant 21: e12892. https://doi.org/10.1111/petr.12892

71. Abraham G, John GT, Sunil S, Fernando EM, Reddy YNV (2009) Evolution of renal transplantation in India over the last four decades. NDT Plus 3:203-207. https://doi.org/10.1093/ndtplus/ sfp178

72. Sethi SK, Bansal SB, Wadhwani N, Tiwari A, Arora D, Sharma R, Nandwani A, Yadav DK, Mahapatra AK, Jain M, Jha P, Ghosh P, Bhan A, Dhaliwal M, Raghunathan V, Kher V (2018) Pediatric ABO-incompatible kidney transplantation: evolving with the advancing apheresis technology: a single-center experience. Pediatr Transplant 22:e13138. https://doi.org/10.1111/petr.13138

73. Kute VB, Agarwal SK, Sahay M, Kumar A, Rathi M, Prasad N, Sharma RK, Gupta KL, Shroff S, Saxena SK (2018) Kidney-paired donation to increase living donor kidney transplantation in India: Guidelines of Indian Society of Organ Transplantation - 2017. Indian J Nephrol 28:1-9. https://doi.org/10.4103/ijn.IJN 36517

74. Kafle MP, Poudyal AK, Chalise PR, Shah DS (2019) Pediatric kidney transplantation in Nepal. Pediatr Transplant 23:e13588. https://doi.org/10.1111/petr.13588

75. Wong G, Howard K, Chapman JR, Chadban S, Cross N, Tong A, Webster AC, Craig JC (2012) Comparative survival and economic benefits of deceased donor kidney transplantation and dialysis in people with varying ages and co-morbidities. PLoS One 7:e29591

76. Jha V, Martin DE, Bargman JM, Davies S, Feehally J, Finkelstein F, Harris D, Misra M, Remuzzi G, Levin A, International Society of Nephrology Ethical Dialysis Task Force (2017) Ethical issues in dialysis therapy. Lancet 389:1851-1856

77. Ramachandran R, Jha V (2013) Kidney transplantation is associated with catastrophic out of pocket expenditure in India. PLoS One 8:e67812. https://doi.org/10.1371/journal.pone.0067812

78. Eke FU, Ladapo TA, Okpere AN, Olatise O, Anochie I, Uchenwa T, Okafor H, Ibitoye P, Ononiwu U, Adebowale A, Akuse R, Oniyangi S (2021) The current status of kidney transplantation in Nigerian children: still awaiting light at the end of the tunnel. Pediatr Nephrol 36:693-699

79. Harris DCH, Davies SJ, Finkelstein F (2019) Increasing access to integrated ESKD care as part of universal health coverage. Kidney Int 95:S1-S33. https://doi.org/10.1016/j.kint.2018.12.005

80. Teerawattananon Y, Dabak SV, Khoe LC, Bayani DBS, Isaranuwatchai W (2020) To include or not include: renal dialysis policy in the era of universal health coverage. BMJ 368:m82. https://oi.org/10.1136/bmj.m82

81. Helmuth ME, Liu Q, Turenne MN (2019) Secular trends in the cost of immunosuppressants after solid organ transplantation in the United States. Clin J Am Soc Nephrol 14:421-430. https://doi. org/10.2215/cjn.10590918 
82. Kumar S, Dansereau EA, Murray CJL (2014) Does distance matter for institutional delivery in rural India? Appl Econ 46:4091-4103. https://doi.org/10.1080/00036846.2014.950836.75

83. Walker RC, Naicker D, Kara T, Palmer SC (2019) Children's experiences and expectations of kidney transplantation: a qualitative interview study. Nephrology 24:647-653. https://doi.org/10.1111/ nep. 13405

84. Van Biesen W, Jha V, Abu-Alfa AK, Andreoli SP, Ashuntantang G, Bernieh B, Brown E, Chen Y, Coppo R, Couchoud C, Cullis B, Douthat W, Eke FU, Hemmelgarn B, Hou FF, Levin NW, Luyckx VA, Morton RL, Moosa MR, Murtagh FEM, Richards M, Rondeau E, Schneditz D, Shah KD, Tesar V, Yeates K, Garcia Garcia G (2020) Considerations on equity in management of end-stage kidney disease in low- and middle-income countries. Kidney Int Suppl 10:e63-e71. https://doi.org/10.1016/j.kisu.2019.11.004

85. Odetunde OI, Okafor HU, Uwaezuoke SN, Ezeonwu BU, Ukoha OM (2014) Renal replacement therapy in children in the developing world: challenges and outcome in a tertiary hospital in Southeast Nigeria. ScientificWorldJournal:903151. https://doi.org/10.1155/ 2014/903151

86. Jafar TH (2009) Organ trafficking: global solutions for a global problem. Am J Kidney Dis 54:1145-1157. https://doi.org/10. 1053/j.ajkd.2009.08.014

87. Melk A, Babitsch B, Borchert-Mörlins B, Claas F, Dipchand AI, Eifert S, Eiz-Vesper B, Epping J, Falk CS, Foster B, Geyer S, Gjertson D, Greer M, Haubitz M, Lau A, Maecker-Kolhoff B, Memaran N, Messner HA, Ostendorf K, Samuel U, Schmidt
BMW, Tullius SG, West L, Wong G, Zimmermann T, Berenguer M (2019) Equally interchangeable? How sex and gender affect transplantation. Transplantation 103:1094-1110. https://doi.org/ $10.1097 / \mathrm{tp} .0000000000002655$

88. Sahay M (2019) Men are from mars, women are from venus: gender disparity in transplantation. Indian J Transplant 13:237-239

89. Iyengar A, Lewin S, Lantos JD (2018) Considering family resources when making medical recommendations. Pediatrics 141: e20171198. https://doi.org/10.1542/peds.2017-1198

90. Luyckx VA, Martin DE, Moosa MR, Bello AK, Bellorin-Font E, Chan TM, Claure-Del Granado R, Douthat W, Eiam-Ong S, Eke FU, et al. (2020) Developing the ethical framework of end stage kidney disease care: from practice to policy. Kidney Int Suppl 10: e72-e77. https://doi.org/10.1016/j.kisu.2019.11.003

91. Luyckx VA, Tonelli M, Stanifer JW (2018) The global burden of kidney disease and the sustainable development goals. Bull World Health Organ 96:414-422D. https://doi.org/10.2471/BLT.17. 206441

92. Luyckx VA, Al-Aly Z, Bello AK, Bellorin-Font E, Carlini RG, Fabian J, Garcia-G, Iyengar A, Sekkarie M, Van Biesen W (2021) Sustainable development goals relevant to kidney health: an update on progress. Nat Rev Nephrol 17:15-32. https://doi.org/ 10.1038/s41581-020-00363-6

Publisher's note Springer Nature remains neutral with regard to jurisdictional claims in published maps and institutional affiliations. 